\title{
AN ANALYSIS OF THE EFFECTS OF THE ECONOMIC POLICY IN SERBIA BY THE MUNDELL-FLEMING MODEL
}

\section{Zoran Grubišić}

Univesity Union, Belgrade Banking Academy, Faculty for Banking, Insurance and Finance $\bowtie$ zoran.grubisic@bba.edu.rs

\section{Sandra Kamenković}

Univesity Union, Belgrade Banking Academy, Faculty for Banking, Insurance and Finance, $\bowtie$ sandra.kamenkovic@bba.edu.rs

UDC

338.246.2:

336.74

Review

paper

Received:

30.10.2014

Accepted:

27.03.2015

\begin{abstract}
The global economic crisis has affected the whole world, including Serbia. Countries with different degrees of development reacted with different measures of economic policy, both monetary as well as fiscal. Economic authorities in Serbia have encountered certain limiting factors in the selection of measures, first of all taking into account the unfinished transition process. This paper will examine whether the applied monetary and fiscal policy in Serbia is adequate according to the position which Serbia occupies by the Mundell-Fleming model, as well as to identify the starting position for future economic policy measures.
\end{abstract}

Keywords: Monetary policy, fiscal policy, Mundell-Fleming model

\section{Introduction}

Prior to the outbreak of the global financial crisis, Serbia had a balanced balance of payments, with the deficit in the current part of the balance of payments and the surplus in the capital section of the balance of payments. The surplus in the capital part was mainly a consequence of the privatization revenues. However, after the outbreak of the crisis in 2008 and 2009 there was a sudden drop in foreign capital inflow, which was not even directly correlated with the level of interest rates. The main consequence was reflected in the large deficit of the 
balance of payments, because now high current deficit abroad could not be covered by the influx of foreign capital. In addition, virtually all macroeconomic indicators in Serbia have worsened. A number of necessary reforms have been postponed and the situation got more complicated. By economic policy measures, the authorities have tried to minimize the effects, but it appears that, apart from the problems caused by the economic crisis, there are still a number of unresolved problems in the Serbian economy. Although repeatedly announced, the reforms, particularly in the area of fiscal policy, are implemented in extremely modest scope, which is not good, especially for the growth and development of the economy.

\section{Theoretical Basis}

The Mundell-Fleming model is named after Robert Mundell and James Fleming. The most important contribution of this model is considered to be the inclusion of trade and international capital movements in macroeconomic models based on the Keynesian IS-LM model (Fleming, Mundell, 1964). This model shows the key macroeconomic variables such as GDP, inflation rate, balance of payments, exchange rates, interest rates and the interaction between them, as well as the impact of fiscal and monetary policy on the internal and external balance. When talking about Fleming's contribution to the model, now known as the Mundell-Fleming model, it is about his work from 1962 in which he analyzed the impact of the decision on the exchange rate regime on the effectiveness of monetary and fiscal policy. In this work, he argues that the expansionary monetary policy is more effective under floating then under fixed exchange rates, either absolutely or relatively in relation to fiscal action. On the other hand, according to Fleming (1962), it is uncertain whether the expansionary effect of fiscal policy measured by the growth of budget expenditures or cutting taxes will be higher or lower under floating or fixed exchange rates.

Given that developing countries and transition economies have not been fully integrated into the international capital market yet, fiscal and monetary policy under a floating exchange rate can be quite effective (Mundell, 1960).

The Mundell-Fleming model consists of the three curves. The IS curve shows the equilibrium points in the commodity market, or various combinations of aggregate output and interest rates in which the aggregate production equals aggregate demand. LM curve shows various combinations of different levels of GDP and the interest rates at which the money market is in equilibrium, that is, where the supply and demand of money are equal. The BP curve shows the various combinations of interest rates and GDP in the situation of balance of payments equilibrium. 
Factors that influence movements of the IS curve, by Mishkin (2006), are the following:

1. Growth of individual consumption (C), shifts function of aggregate demand upward, leading to an increase in aggregate output (Y) and an increase in the interest rate (i) and graphically the IS curve shifts to the right

2. Growth of planned investment (I), increases aggregate demand and consequently, aggregate output grows (Y) and the increase in the interest rate (i), shifting graphically the IS curve to the right

3. An increase in government spending $(G)$ increases aggregate demand and consequently, growth in aggregate output $(\mathrm{Y})$ and the increase in the interest rate (i), and the IS curve shifts to the right

4. Growth in taxes (T), does not directly affect aggregate demand, but reduces the amount of income that is available, and reduces individual consumption. Reducing individual consumption leads to a decrease in aggregate demand, that is the fall in aggregate output $(\mathrm{Y})$ and the decline in interest rates (i) and the IS curve shifts to the left

5. The increase in net exports (NX) increases aggregate demand, which increases aggregate output $(\mathrm{Y})$ and increases the interest rate (i), and the IS curve shifts to the right

Factors influencing the shift of the LM curve are the following:

1. The growth of the money supply (Ms), shifts the LM curve to the right, which, along with the constant production, leads to a reduction in interest rates, which increases production output $(\mathrm{Y})$ at the new equilibrium point, reducing the interest rate (i).

2. Growth in the demand for money (Md), at a constant level of production, shifts the LM curve to the left, and the interest rate rises, reducing the production output $(\mathrm{Y})$ at the new equilibrium point, and increasing the interest rate (i).

Factors which influence movements of the BP curve are the following:

1. Balance of payments surplus places the cross-section of the IS and LM curves to the left of the BP curve which shows a balance of payments surplus. The surplus is due to the fact that the level of GDP is too low and / or because the level of interest rates is too high in relation to the overall balance

2. Balance of payments deficit places the intersection of the IS and LM curves right of the BP curve, which means that the level of GDP is too high and / or the level of domestic interest rates is too low relative to the equilibrium sizes, which causes the appearance of payments deficit. 
It should be noted that the conclusions of the IS-LM model of the closed and the IS-LM model of the open economy is different. In a closed economy model, both fiscal and monetary policies are equally effective, and the overall efficiency depends on the slope and elasticity of the IS and LM curve, where the BP curve is completely horizontal. In the case of the open economy, fiscal policy is completely ineffective as opposed to monetary, which is very efficient.

\section{Monetary Policy in Serbia during the Year 2012}

At the end of 2012 macroeconomic indicators in Serbia showed a tendency of slight recovery. Economic activity recorded moderate growth, inflation was a stagnant and foreign deficit was reduced. However, a deeper analysis indicates that only certain sectors show recovery, like automotive, oil and pharmaceutical industries, while the rest of the economy is still in recession. If we analyze the unemployment rate as a parameter of recovery, its rate in Serbia shows that it has not recovered yet. In addition, conditions in the rest of Europe and the continuation of the recession aggravated the possibility of economic recovery in Serbia. Foreign and fiscal deficits remain high and the amount of public and external debt does not preclude the possibility of the outbreak of the debt crisis.

Table 1 - Macroeconomic Indicators in Serbia

\begin{tabular}{||l|l|l|l|l|l|l||}
\hline & $\mathbf{2 0 0 7}$ & $\mathbf{2 0 0 8}$ & $\mathbf{2 0 0 9}$ & $\mathbf{2 0 1 0}$ & $\mathbf{2 0 1 1}$ & $\mathbf{2 0 1 2}$ \\
\hline GDP & $5,4 \%$ & $3,8 \%$ & $-3,5 \%$ & $1,0 \%$ & $1,6 \%$ & $-1,5 \%$ \\
\hline Inflation & $11,0 \%$ & $8,6 \%$ & $6,6 \%$ & $10,3 \%$ & $7,0 \%$ & $12,2 \%$ \\
\hline $\begin{array}{l}\text { Current account (in } \\
\% \text { of GDP) }\end{array}$ & $-17,7 \%$ & $-21,6 \%$ & $-6,6 \%$ & $-6,7 \%$ & $-9,1 \%$ & $-10,7 \%$ \\
\hline
\end{tabular}

Source: National Bank of Serbia

Monetary policy in Serbia at the end of 2012 was extremely restrictive, which led to a decrease in inflation. However, due to the improvement in the macroeconomic situation and the announced tightening of fiscal policy, monetary policy restrictiveness could be reduced. In addition to being reduced, from November 2012 inflation stagnated at the same level. It is estimated that the impact of systemic factors was exhausted, such as fiscal deficit and the exchange rate depreciation in the first half of 2012, as well as the impact of oneoff factors such as drought and tax increases which have contributed to the increase in inflation. It is expected that in the forthcoming months, inflation would be low, with occasional jumps, caused by increasing administratively controlled prices. During 2012, from January to August the dinar experienced nominal and real depreciation to be followed by strong appreciation in the period from August to October, and was finally fairly stable during the period from October to December. The appreciation of the dinar has been caused by a 
restrictive monetary policy and foreign exchange inflows arising from borrowing. Consequently, there has been disinflation, but it also caused a reduction in the price of competitiveness of the Serbian economy. The positive side of the appreciation of the dinar is the fact that the state had less expenses for interest rates, given that the greater part of the Serbian debt is denominated in foreign currency. Interest rate expenses in 2012 were RSD 3.6 billion, which was less than planned in September. A reduction of monetary policy restrictiveness would aim to reduce the deficit in the current account balance through moderate depreciation of dinar. The depreciation would have a long term positive impact on economic growth and employment, but certainly it would have to be gradual so as not to trigger high inflation or high losses by the debtors who have debts indexed in foreign currency. Gradual depreciation is intended to prevent the sudden depreciation that could be caused by a sudden decrease in the inflow of foreign capital. Also, the planned increase in fiscal policy restrictiveness leaves space for reducing monetary policy restrictiveness.

Table 2 - Foreign Currency Reserves of the National Bank of Serbia in the Period 2007-2012 (in mill EUR)

\begin{tabular}{|l|c|c|c|c|c|c||}
\hline Year & $\mathbf{2 0 0 7}$ & $\mathbf{2 0 0 8}$ & $\mathbf{2 0 0 9}$ & $\mathbf{2 0 1 0}$ & $\mathbf{2 0 1 1}$ & $\mathbf{2 0 1 2}$ \\
\hline Total & $9.634,0$ & $8.162,0$ & $10.601,9$ & $10.001,6$ & $12.058,2$ & $10.914,7$ \\
\hline
\end{tabular}

Source: National Bank of Serbia

Table 3 - Interventions by the National Bank of Serbia on Interbanking Foreign Currency Market Cumulative (in mill EUR)

\begin{tabular}{|l|l|l|l|l|l|l|l|l||}
\hline \hline Year & \multicolumn{5}{|c|}{2011} & \multicolumn{4}{c||}{2012} \\
\hline Quarter & Q1 & Q2 & Q3 & Q4 & Q1 & Q2 & Q3 & Q4 \\
\hline Total & 5 & -30 & -30 & -30 & -498 & -1288 & -1348 & -1343 \\
\hline
\end{tabular}

Source: National Bank of Serbia

At the end of the year the trend of reducing the deficit in the current account continued, but there has been a shift in the capital balance in terms of a significant surplus. What is convenient is that the reduction in the deficit in the current part was caused by the growth of exports, and on the other hand, what is unfavorable is that the surplus in capital account was made by borrowing on behalf of the state, which is certainly not sustainable in the long run. A possible consequence of such a scenario is a situation in which after a sudden stop of capital inflow there comes strong depreciation of the dinar and foreign exchange reserves of the National Bank of Serbia, followed by a rise in inflation. It should also be noted that despite the reduction of the deficit, the current part of the balance of payments is still high, and it would be necessary to work on its further reduction. The foreign debt at the end of 2012 reached a 
level of about $90 \%$ of GDP, and the cost of its funding will be extremely high, thus threatening the possibility of balance of payments crisis.

Table 4 - Foreign Exchange in Serbia during the Year 2012

\begin{tabular}{|l|c||}
\hline Date & Mean currency exchange rate of NBS \\
\hline $30-12-2011$ & 104,6409 \\
\hline $31-01-2012$ & 106,0620 \\
\hline $29-02-2012$ & 110,1866 \\
\hline $30-03-2012$ & 111,3643 \\
\hline $30-04-2012$ & 111,8981 \\
\hline $31-05-2012$ & 116,6121 \\
\hline $29-06-2012$ & 115,8203 \\
\hline $31-07-2012$ & 117,7306 \\
\hline $31-08-2012$ & 118,4517 \\
\hline $28-09-2012$ & 115,0320 \\
\hline $31-10-2012$ & 113,2836 \\
\hline $30-11-2012$ & 112,6378 \\
\hline $31-12-2012$ & 113,7183 \\
\hline
\end{tabular}

Source: National Bank of Serbia

\section{Fiscal Policy in Serbia during the Year 2012}

The fiscal policy in Serbia at the end of 2012 was very expansive, but it was expected that in 2013 it would be much more limited, as the process of fiscal consolidation should follow. The fiscal deficit at the end of the year reached a level of $6.6 \%$ of GDP, or RSD 217 billion, which is at least $0.5 \%$ more compared to the amount planned in the framework of fiscal strategy that was adopted in November.The high fiscal deficit is the result of traditionally high spending after the elections. It was in the fourth quarter mainly generated through strong growth in spending on subsidies and a slight increase in capital expenditure, while other categories of public expenditures and public revenues declined slightly. Public revenue in relation to the plan were lower by about 25 billion dinars, which can be considered a large deviation, keeping in mind that the revised budget was prepared in September, and that at this point of time there was three months to the end of the year. Revenues from excise taxes on tobacco mostly did not fit into the plan, as well as non-tax revenue and VAT. In terms of declining public expenditure, reduction in relation to the plan amounted to about RSD 30 billion, and mostly reflected in the weaker execution of planned expenditures for procurement of goods and services. It is interesting 
to note the result of research conducted by Lukovic and Grbić (2014) which analyzes the relationship between government expenditures and revenues in Serbia between 2003 and 2012. Using the Toda-Yamamoto method has been established that there is unidirectional causality ranging from government expenditure to government revenue. In the context of the results recommendation for the authorities is to preserve in the process of reducing government expenditure, because it is the only optimal way to reduce the budget deficit in the long run. The effects of fiscal consolidation should certainly be positive, but a longer period of time would be needed for the assessment of the effects. However, it is expected that the fiscal deficit will be higher than the planned 3.6\% of GDP and will reach a level of around $4.5 \%$ of GDP, so there must be a new borrowing. Therefore, additional austerity measures are necessary so that fiscal deficit does not to cross $4 \%$ of GDP. What the Fiscal Council proposed was to adopt and follow the quarterly targets of budget execution, in order to take timely corrective actions. However, that proposal has not been adopted yet.

The government's fiscal strategy in 2013 predicted to initiate reform of wages and employment in the public sector, to work on the completion of the process of restructuring the state-owned enterprises, to reform public enterprises, develop a social map of the population and begin reforms of the pension system.

Table 5 - Fiscal Balance of the Republic of Serbia (in \% of GDP) during the Period 2007-2012

\begin{tabular}{||c|c|c|c|c|c|c|}
\hline Year & $\mathbf{2 0 0 7}$ & $\mathbf{2 0 0 8}$ & $\mathbf{2 0 0 9}$ & $\mathbf{2 0 1 0}$ & $\mathbf{2 0 1 1}$ & $\mathbf{2 0 1 2}$ \\
\hline $\mathbf{\%}$ & $-1,9$ & $-2,58$ & $-4,49$ & $-4,56$ & $-4,98$ & $-6,63$ \\
\hline
\end{tabular}

Source: Table made by authors according to data from the Quarterly monitors

It should be noted that in the period before the outbreak of the global economic crisis in many countries fiscal policy was largely reduced to the automatic stabilizers and the discretionary fiscal measures were observed with skepticism (Arestis, 2011). However, with the outbreak of the economic crisis, it has become clear that the market will not be able to solve the resulting economic problems by its own actions, and the states resorted to a kind of recovery strategies. The first response to the crisis were stabilization monetary measures, which increased liquidity of the financial system with injections of funds, while central banks around the world lowered the referential interest rates (Jevđović, 2013). However, the effectiveness of monetary policy was limited by the end of 2008, when the basic interest rate was close to zero. With monetary policy which with the arrival to the so-called zero boundary became ineffective and economic system approaching collapse, the fiscal policy proved to be the only remaining tool. Fiscal stabilization packages were introduced, which supported aggregate demand and saved the economy from a dramatic decline. 
Public debt at the end of 2012 amounted to RSD 17.7 billion $(61.3 \%$ of GDP). The growth of indirect public debt, according to the guarantees issued by the state to public companies to enable them to borrow continued additionally increasing the level of indebtedness of the country, which is not a favorable circumstance. If it is assumed that the planned objectives in the area of macroeconomic and fiscal developments in 2013 would be achieved, and that the real exchange rate would not significantly change, it is expected that Serbian public debt at the end of 2013 would be at the level of $62-63 \%$ of GDP. The trend of growth of public debt is unsustainable and certainly leads to a crisis, and it is necessary to react as quickly as possible. In addition, it should be noted that the Government is obliged, under the Law on the Budget System, to begin a program to reduce the public debt when it exceeds the limit of $45 \%$ of GDP. Also, when the public debt in GDP constantly increases, the investors quickly conclude that the country's public finances are on an unsustainable path and will stop lending money, which is definitely an introduction to the public debt crisis.

Table 6 - Trends in Public Debt in Serbia (in \% of GDP) in the period 2007-2012

\begin{tabular}{|c|l|l|l|l|l|l||}
\hline Year & $\mathbf{2 0 0 7}$ & $\mathbf{2 0 0 8}$ & $\mathbf{2 0 0 9}$ & $\mathbf{2 0 1 0}$ & $\mathbf{2 0 1 1}$ & $\mathbf{2 0 1 2}$ \\
\hline $\mathbf{\%}$ & 30,9 & 29,2 & 34,8 & 44,6 & 46,9 & 59,4 \\
\hline
\end{tabular}

Source: Table made by the authors according to the data from the Quarterly monitors

\section{The Mundell-Fleming Model in Serbia}

Measures in the field of monetary policy can be grouped as follows:

1. The increase in the referential interest rates from January 2012 to December 2012 was $9.50 \%$ to $11.25 \%$.

2. Controlled depreciation of the dinar in the period from January to October, by which foreign exchange reserves were consumed, but it had an expansionary effect on economic activity, as exports became more profitable, followed by strong appreciation in the period from August to October.

3. Monetary contraction due to a decrease in foreign exchange reserves in the total balance for 2012 .

The overall effect of monetary policy was restrictive due to the fall in the money supply, the sale of foreign exchange and withdrawal of dinar. Restrictive effect is stronger than the effect of the controlled depreciation of dinar, which has an expansive effect.

The most appropriate measure would be to allow greater depreciation of the dinar, as monetary tightening, and thus the hindering of the demand would be weaker. A small drop in demand and turning from imported to domestic 
products, due to the depreciation, would lead to a weaker hindering of economic activity and would cost less in foreign exchange reserves. The disadvantage of higher depreciation would be an increase in debts because loans in Serbia are predominantly indexed in EUR.

Measures in the area of fiscal policy could be summarized as follows:

1. The increase in the deficit in public spending to $6.6 \%$ of GDP

2. The increase in public spending as the fulfillment of election campaign promises, through the growth of subsidies and increase in capital spending

3. Reduced budget revenues from collection of VAT, excise, duties

The overall effect of fiscal policy is expansionary, which reduces the recession, but public sector wages and pensions are unsustainable in 2013 without additional borrowing. In addition, in 2013 the start of the fiscal consolidation process was announced.

Measures more appropriate to the current situation would be freezing, even a reduction in public sector wages and pensions, termination of employment, reduction of discretionary budget allocation, reducing transfers to health care and to local self-governments.

When there is a state of imbalance in the economy, primarily the internal one, as well as the external, policymakers react using adjustment policies, first of all monetary and fiscal, so as to bring the economy back to equilibrium. However, it should be noted that there is another option and that is not to take any action, but to wait, because with the passing of time, the internal equilibrium would be established on its own. Though, the cost of such passive adjustment can be too high. Policymakers rarely choose not to take action and wait for the market mechanism to respond to the imbalance.

The Mundell-Fleming model is one way to synthetically show the effects of the impact of the crisis on Serbia, but also the effects of economic policy of the state. Also, we get a description of the starting point necessary for consideration of future monetary and fiscal policy measures. It should be noted that it is about an approximate or styled description that will give you the basic directions of movement (Petrović, 2009).

Before the crisis, Serbia had a balanced balance of payments, which was the result of the high current account deficit (goods and services) and also compensating high surplus of capital and financial transactions. The position of Serbia, and a balanced balance of payments is shown in Figure 1, where the Balance of Payments curve (BP) passes through the intersection of the other two curves (IS and LM). It should be noted that Serbia needs for compensatory investments to fund large current account deficit abroad, is a perennial problem and in the future could significantly hamper the establishment of external equilibrium. 
Certainly, it would be important to examine the inclines of the IS and LM curves in the field of a closed economy, as this would determine the elasticity of the impact of economic policy instruments (primaly interest rates according to the IS-LM model) to establish internal economic balance and equilibrium level of economic activity. Certainly, there remains a major challenge for the simultaneous establishment of internal and external balance in the field of open macroeconomics that can be monitored via the Mundell-Fleming model.

Figure 1 Serbia According to the Mundell-Fleming Model prior to the Impact of the World Crisis



Figure 2 Effects of the Monetary and Fiscal Policy at the end of 2012 in Serbia

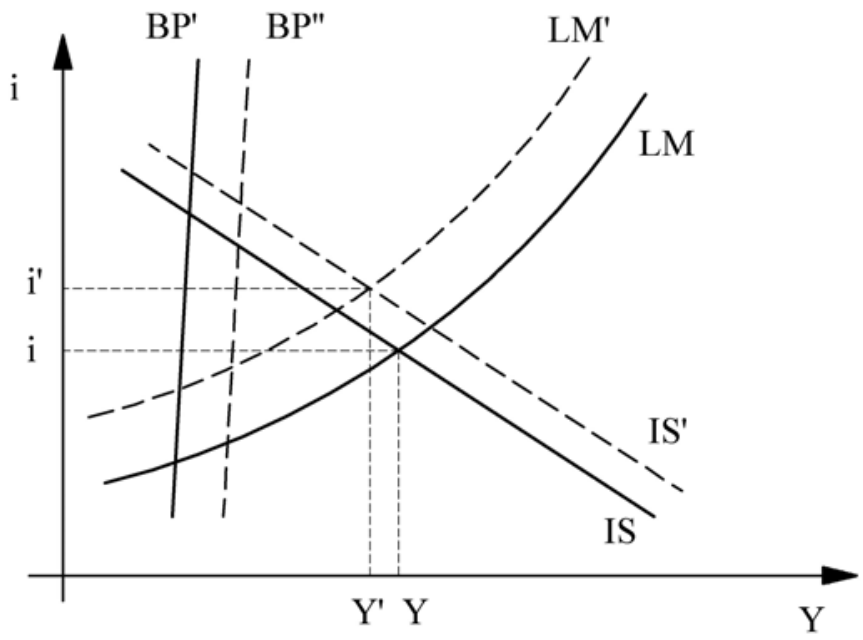


Monetary tightening, namely a reduction in the money supply causes the LM curve shifts to the left (LM-LM ') which results in the reduction in aggregate demand, and through it, the decrease of economic activity, but also causes reduction of imports and improvement of the trade deficit. In contrast, the expansionary fiscal policy shifts the IS curve to the right and leads to an increase in aggregate demand, stimulation of economic activity and an increase in imports. On the other hand, the crowding-out effect reduces the shift in the IS curve to the right, because by the increase in interest rates private sector investment are falling. Finally, the currency depreciation has an expansionary effect on economic activity, turning demand from foreign to domestic products, or moving the IS curve to the right. The overall expansionary effect of fiscal policy and the depreciation is included in the movement from IS to IS '. Currency depreciation also affects the improvement in the trade deficit, and through it it influences the balance of payments as it is shown in the Figure by the movement of the BP 'to BP. "

Dashed lines show the position where the Serbian economy stood after the impact of the economic crisis and economic policy responses at the end of 2012. New sectional IS 'and LM' curves is to the left of the previous one, showing that there occured the decline in production, or that the effects of monetary contraction surpassed the effects of expansionary fiscal policy and the depreciation of dinar. Also, the new intersection of IS and LM approached BP curve, which shows that the current account deficit was reduced. This reduction was due to reduced demand and the consequent reduction in imports. Finally, the new cross-section implies a higher level of interest rates.

Additional reduction in the current account deficit and move of BP 'to the right can be expected due to the depreciation of dinar, under the terms of the Marshall Lerner theorem, but only after a certain period (Rose, 1991).

\section{Conclusion}

Economic authorities reacted to economic crisis by applying certain measures of monetary and fiscal policy. This paper has aimed to analyze actions taken through the point of view of the Mundell-Fleming model, to evaluate their effectiveness on the one hand, and to set the starting position for future economic policies on the other. Analysis has shown that certain measures have been effective, but that some were not adjusted state of the Serbian economy at that time. What is certain is that fiscal consolidation is inevitable in order to reduce the fiscal deficit and public debt, whose level can be said to be critical threatening to cause the debt crisis in the country. 


\section{References}

Arestis, P. (2011) "Fiscal policy is still an effective instrument of macroeconomic policy“, Panoeconomicus, 58(2): 143-156.

Fleming, M .(1962) Domestic Financial Policies Under Fixed and Under Floating Exchange Rates, IMF Staff Papers, IMF, vol. 9, pp. 369-79.

Fleming, M., Mundell, R. (1964) Official Interventions on the Forward Exchange Market: A Simplified Analysis, IMF Staff Papers, IMF, Vol.11, pp 1-19.

Jevđović,G. (2013) „Suština i aktuelnost Mandel-Flemingovog modela“, Bankarstvo, 42 (2): $90-121$.

Luković, S., Grbić, M.(2014) „Testiranje povezanosti državnih prihoda i državnih rashoda u Srbiji“, Ekonomske teme, 52(2):135-145.

Mishkin, F. (2006) Monetary economics, banking and financial markets, Serbian Edition. Belgrade: Data Status.

Mundell, R. (1960) "The Monetary Dinamics of International Adjustment under Fixed and Flexible Exchange Rates“, Quarterly Journal of Economics, 74 (2): 227-257.

National Bank of Serbia, www.nbs.co.rs

Petrović, P. (2009) "Efekat svetske finansijske krize na Srbiju i odgovor ekonomske politike“, Ekonomika preduzeća, 57 (1/2): 43-50.

The foundation for the Advancement of Economica (FREN) (2012) Quarterly monitor of economic trends and policies in Serbia, numbers 28-31, Belgrade, www.fren.org.rs

Rose, A. K. (1991) "The role of exchange rates in a popular model of international trade: Does the 'Marshall-Lerner' condition hold?" Journal of International Economics 30 (3-4): 301-316.

\section{ANALIZA EFEKATA MERA EKONOMSKE POLITIKE U SRBIJI PREKO MUNDELL-FLEMINGOVOG MODELA}

Apstrakt: Svetska ekonomska kriza pogodila je čitav svet, uključujući i Srbiju. Zemlje različitog stepena razvijenosti su reagovale različitim merama ekonomske politike, kako monetarne, tako i fiskalne. Ekonomske vlasti Srbije su u odabiru mera imale određene ograničavajuće faktore, imajući u vidu pre svega nedovršen proces tranzicije. Predmet analize ovog rada biće ispitati da li je primenjena monetarna i fiskalna politika u Srbiji adekvatna poziciji u kojoj se Srbija po Mundell-Flemingovom modelu nalazi, kao i koja je početna pozicija za buduće mere ekonomske politike.

Ključne reči: Monetarna politika, fiskalna politika, Mundell-Fleming model 